\title{
Effect of Sex Hormones on the Activity of Protein Kinases in Rat Ventral Prostate and Uterus
}

\author{
Shogo ICHII, Yukio IWANAGA AND Akemi IKEDA \\ Division of Physiology, Institute of Steroid Research, \\ Tottori University School of Medicine, Yonago
}

\begin{abstract}
Synopsis
To elucidate the physiological role of cAMP-dependent and -independent protein kinase and cAMP-binding protein in regulation of cellular function and metabolism, activity of the protein kinases and capacity of the cAMP-binding protein were assayed in the ventral prostate and the uterus from rats of various hormonal statuses. Castration caused a significant elevation in the activity of both cAMP-dependent and -independent protein kinase and administration of testosterone to castrated rats abolished the effect of castration on the enzyme activity. In the uterus, administration of estradiol to immature rats evoked a significant decrease in the cAMP-dependent activity but not in the cAMP-independent activity of the enzyme. Deprival of the sex hormones caused an increase in the cAMP-binding capacity in both the ventral prostate and uterus. Physiological implications of these observations were discussed.
\end{abstract}

It is now widely recognized that adenosine-3', 5'-cyclic monophosphate (cAMP) plays an important role as an intracellular mediator for a number of non-steroidal hormones. While, in the mode of action of steroidal hormones, a few report has appeared concerning to the participation of cAMP in the physiological regulation of their target tissues. Hechter et al. (1967), Griffin and Szego (1968) and Sharma and Talwar (1970) have reported that cAMP stimulates the uptake and incorporation of uridine into RNA and increases amino acid incorporation into protein of uterus. An increased rate of cAMP formation in immature rat uterus after estradiol treatment was recently reported by Thomas et al. (1972). Singhal et al. (1970) also found a testosterone-like induction of certain enzyme activities by cAMP administration to castrated and immature rats. However, whether or not cAMP acts as a mediator of

Received for publication December 19, 1972. steroidal hormones seems to need further studies, since other nucleotides also exhibited the similar physiological effect (Hechter et al., 1967) and the participation of catecholamines released after steroidal hormone administration remains uncertain.

Recent works have shown the presence of phosphoproteins and cAMP-sensitive protein kinases in various tissues throughout the animal kingdom (Kuo and Greengard, 1969; Kuo et al., 1970). These observations lead to a concept that cAMP acts essentially within the cell by the activation of protein kinases but direct evidences to support this concept have not been provided except certain instances; phosphorylase activation and glycogen synthetase inhibition in the skeletal muscle (Walsh et al., 1968; Appleman et al., 1964), and lipase activation in the adipose tissue (Corbin et al., 1970; Huttunen et al., 1970), etc. Phosphorylation of ribosomes (Walton et al., 1971; Blat and Loeb, 1971), plasma membrane-associated proteins (Shlatz and 
Marinetti, 1971) and histones (Chaubaut et al., 1971) were reported but physiological implications of these findings have not been fully elucidated.

In a previous report from this laboratory, one of the present authors determined cAMP level, cAMP-dependent and -indpendent protein kinase activity and cAMP-binding capacity in rat adrenal gland after ACTH stimulation to examine their interrelationships in the functional regulation of the cell (Ichii, 1972). In the present study we examine the protein kinase activity and cAMP-binding capacity in the ventral prostate and the uterus from rats of various hormonal statuses. The purpose of the present work was to obtain informations about the physiological role of protein kinases and cAMP-binding protein in the metabolic regulation of the tissues under the influence of sex hormones.

\section{Materials and Methods}

\section{Animals}

For the study of ventral prostate, male Wistar rats weighing approx. $350 \mathrm{~g}$ were used. For the assay of uterus, tissues were obtained from female Wistar rats of 40-50 g (immature, age 21-23 days) and 270 $300 \mathrm{~g}$ (adult) body weight, respectively. They were fed ad libitum with balanced diet (Clea CA-1, Nippon Clea K. K. Tokyo) and kept in a room of constant temperature $\left(25^{\circ}\right)$ with a 8 a.m. -8 p.m. daylight cycle. Castration was performed via scrotal route under ether anesthesia. Testosterone treatment was performed by injecting subcutaneously with daily dose of $2 \mathrm{mg}$ testosterone propionate per head dissolved in $0.2 \mathrm{ml}$ of cotton seed oil. Estradiol was administered intraperitoneally as $20 \%$ ethanolic solution with daily dose of $5 \mu \mathrm{g}$ per head. Animals received castration and the replacement therapy were sacrificed $72 \mathrm{hr}$ after operation. Immature female rats received estrogen treatment were sacrificed $24 \mathrm{hr}$ after estrogen administration.

\section{Tissue preparation}

Aminals were sacrificed by exsanguination and removed tissue was immediately homogenized in 20 volumes of $50 \mathrm{mM}$ Tris buffer $(\mathrm{pH} 7.0)$ containing $4 \mathrm{mM}$ EDTA. The homogenate was centrifuged at $10,000 \times \mathrm{g}$ for $20 \mathrm{~min}$ followed by $150,000 \times \mathrm{g}$ for
60 min. More than $90 \%$ of the cAMP-dependent and -independent protein kinase activity was recovered in this supernatant fraction either from rat ventral prostate or uterus, therefore this fraction was used throughout this experiment. The supernatant fraction was dialyzed against large volumes of $10 \mathrm{mM}$ Tris buffer (pH 7.4) containing $6 \mathrm{mM}$ 2-mercaptoethanol for $16 \mathrm{hr}$ and an aliquot of this dialyzate was used for the assay of the protein kinases and another aliquot was used for the determination of cAMP-binding capacity and protein content.

\section{Assay of protein kinase activity}

The activity of cAMP-dependent and -independent protein kinase was determined by the rate of histone phosphorylation using $\gamma-{ }^{32} \mathrm{P}$-ATP as the donor of phosphate in the presence or the absence of CAMP which was essentially the same as that described by Chaubaut et al. (1971). Incubations were carried out at $30^{\circ}$ for $10 \mathrm{~min}$ in the $0.45 \mathrm{ml}$ reaction mixture containing $50 \mathrm{mM}$ of Tris buffer $(\mathrm{pH} 6.5), 5 \mathrm{mM}$ of $\mathrm{MgCl}_{2}, 4 \mathrm{mM}$ of NaF, $2 \mathrm{mM}$ of theophylline, $200 \mu \mathrm{g}$ of calf thymus histone (Sigma Chemical Co., Mo. U.S.A.), $0.5 \mu \mathrm{Ci}$ of $\gamma-{ }^{32} \mathrm{P}$-ATP (15 $\mu \mathrm{M}$, specific activity $800 \mathrm{mCi} / \mathrm{mmole}$, The Radiochemical Centre, Amersham, England) and dialyzed cytosol (approx. $100 \mu \mathrm{g}$ as protein) in the presence or the absence of $5 \mu \mathrm{M}$ cAMP (Sigma Chemical Co., Mo. U.S.A.). The reaction was terminated by adding $0.5 \mathrm{ml}$ of ice-cold $25 \%$ trichloroacetic acid and the solution was filtered on a Millipore filter (HA $0.45 \mu, 25 \mathrm{~mm}$ ). The filter was washed with $25 \mathrm{ml}$ of ice-cold $5 \%$ tricholroacetic acid and the dried filter was counted in a liquid scintilation spectrometer. A unit of enzyme activity was defined as the amount of enzyme which transfer 1 pmole of ${ }^{32} \mathrm{PO}_{4}$ from $\gamma-{ }^{32} \mathrm{P}$-ATP to acid insoluble materials. Under these incubation conditions the reaction proceed linearly at least for $30 \mathrm{~min}$ within a range of protein concentration of the cytosols upto $350 \mu \mathrm{g}$ per tube.

\section{Determination of cAMP-binding capacity}

cAMP-binding capacity in dialyzed cytosol fraction was determined by the method of Chaubaut et al. (1971). The reaction mixture was prepared by adding dialized cytosol fraction (approx. $70 \mu \mathrm{g}$ as protein) in $0.4 \mathrm{ml}$ containing $1 \mu \mathrm{Ci}$ of ${ }^{3} \mathrm{H}-\mathrm{cAMP}$ (40 pmoles, specific activity $24.1 \mathrm{Ci} / \mathrm{mmole}$, New England Nuclear Corp., Mass. U.S.A.), $50 \mathrm{mM}$ of Tris buffer ( $\mathrm{pH} 7.5$ ), $10 \mathrm{mM}$ of $\mathrm{MgCl}_{2}, 8 \mathrm{mM}$ of theophylline and $6 \mathrm{mM}$ of 2-mercaptoethanol. Incubations were carried out for $2 \mathrm{hr}$ at $0^{\circ}$ and a Millipore filter (HA $0.45 \mu, 25$ $\mathrm{mm}$ ) was used to separate the free from the proteinbound cAMP. The filter was washed with $20 \mathrm{~m} l$ of the ice-cold buffer solution used for the incubation and the radioactivity retained in dried filter was 
counted in a liquid scintillation spectrometer. Under these conditions, the amount of cAMP bound to protein was proportional to protein concentration of the cytosol at least upto $500 \mu \mathrm{g}$ per tube.

\section{Other analytical method}

Protein was determined by the method of Lowry et al. (1951). Radioactivity of ${ }^{32} \mathrm{P}$ and ${ }^{3} \mathrm{H}$ was determined in $10 \mathrm{ml}$ toluene containing $0.4 \%$ DPO and $0.01 \%$ POPOP using a Tri-Carb liquid scintillation spectrometer model 3380 .

\section{Results and Discussion}

As summarized in Table 1, castration caused a significant elevation in the activity of both cAMP-dependent and -independent protein kinase. Replacement therapy of castrated rats with testosterone propionate completely abolished the effect of castration on the enzyme activity. Few enzymes have been recognized to be increased in atrophied tissues after castration. It is known that after castration the cytoplasmic volume and protein content of a prostate epitherial cell gradually decreases, then the high specific activity of the enzyme in castrated prostate could be resulted if one assumes that this enzyme has relatively

Table 1. Protein kinase activity in prostate from control, castrated and testosterone-treated castrated rat

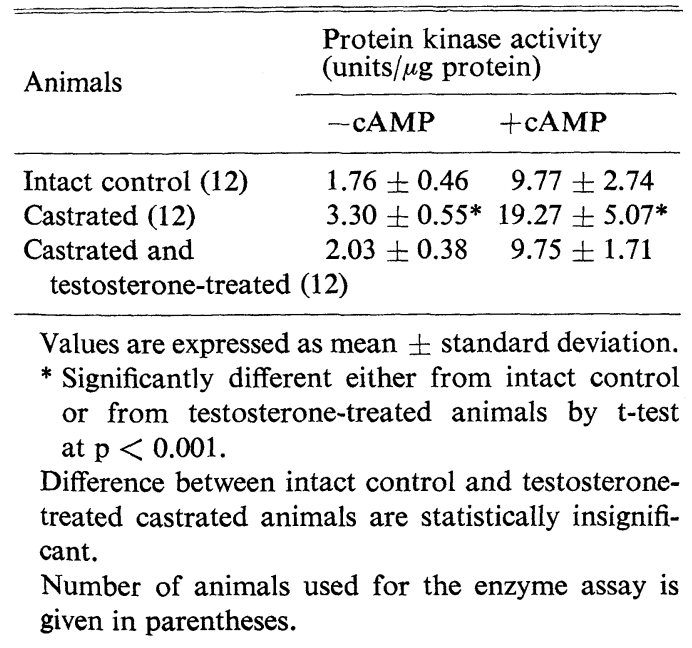

long biological half-life. Therefore the high specific activity of the enzymes in the prostate was not necessarily the result of increased rate of enzyme formation after castration. Phosphorylation of nuclear protein with ${ }^{32} \mathrm{P}$ from $\gamma-{ }^{32} \mathrm{P}-\mathrm{ATP}$ in rat ventral prostate was reported by Ahmed (1971). The same author also reported that the rate of this incorporation of ${ }^{32} \mathrm{P}$ into phosphoproteins of ventral prostate nuclei was decreased after castration and this was completely prevented by administration of testosterone (Ahmed, 1971). The result obtained in the present study seems to be at variance with that by Ahmed (1971), but the in vitro assay of the enzyme activity does not always reflect the functional status of the cell in vivo.

In the uterus, administration of estradiol to immature rats caused a significant decrease in the activity of cAMP-dependent activity, while no significant changes were observed in cAMP-independent activity of the enzyme after the hormone treatment (Table 2). Uteri obtained from adult rats exhibited higher enzyme activity assayed in the absence of cAMP than that of the immature rats and this might be attributable to the difference in the cellular population between uteri of adult and immature animals. There seems to be a possibility that the changes in the enzyme

Table 2. Protein kinase activity in uterus from adult, immature and estrogen-treated immature rat

\begin{tabular}{lcc}
\hline & \multicolumn{2}{c}{$\begin{array}{c}\text { Protein Kinase Activity } \\
\text { (units } / \mu \mathrm{g} \text { protein) }\end{array}$} \\
\cline { 2 - 3 } Animals & -cAMP & +cAMP \\
\hline Adult (6) & $18.68 \pm 6.11^{*}$ & $80.28 \pm 8.99$ \\
Immature (14) & $8.56 \pm 0.92$ & $78.10 \pm 6.07$ \\
Estradiol-treated & $7.90 \pm 1.09$ & $49.21 \pm 3.11^{* *}$ \\
immature (7) & \\
\hline Values are expressed as mean \pm standard deviation. \\
$*$ Significantly different from other groups at \\
p < 0.005. \\
** Significantly different from other groups at \\
p < 0.01. \\
Number of animals used for the enzyme assay is \\
given in parentheses.
\end{tabular}


activity after estrogen administration observed in the present study were mediated by other factor than the direct effect of the estrogen. However, elevated level of the intracellular cAMP after estrogen administration (Thomas et al., 1972), and the potentiation of estrogen action by administration of theophylline were reported (Lafreniere and Singhal, 1971), therefore it was reasoned that the decreased cAMP-dependent activity of the enzyme was the result of dissociation of the regulatory subunit from the catalytic subunit of the cAMP-dependent enzyme after estrogen administration, as the manner proposed by Gill and Garren (1971) and Yamamura et al. (1971). Increased rate of dissociation in cAMP-dependent protein kinase was observed in the lymphocyte after phytohemagglutinin (Cross and Ord, 1971) and in the liver after glucagon (Takeda and Ohga, 1972). However, the result of the present experiment does not seem to be simply attributable to dissociation of the enzyme, since the cAMP-independent activity of the enzyme in the uterus showed no significant changes after estrogen administration. The similar decrease in the cAMPdependent enzyme activity was noticed in rat adrenal gland after ACTH administration (Ichii, 1972).

Administration or deprival of sex hormones also influenced on the cAMP-binding capacity in cytosols from rat ventral prostate and uterus (Table 3). The ventral prostate from castrated rats and the uterus from immature rats showed higher cAMP-binding capacity than the respective counterparts; deprival of the sex hormones caused an increase in the binding capacity and replacement therapy diminished the binding capacity in the target tissues. If almost all the binding of cAMP in the cell is explained for the regulatory subunit of the enzyme, increased capacity of the cAMP-binding should reflect to a high ratio of the cAMP-dependent to -independent activity of the enzyme. This seems to be a case in the uterine enzyme (Table 2 ) but does not seem to be a case in the ventral prostate (Table 1);
Table 3. cAMP-binding activity in rat prostate and uterus under various experimental conditions

\begin{tabular}{lc}
\hline Animals & $\begin{array}{l}\text { cAMP-binding Activity } \\
\text { (pmoles/mg protein) }\end{array}$ \\
\hline Prostate & \\
$\quad$ Intact (8) & $1.77 \pm 0.39$ \\
Castrated (7) & $2.62 \pm 0.42^{*}$ \\
Castrated and & $1.81 \pm 0.33$ \\
$\quad$ testosterone-treated (8) & \\
Uterus & \\
Adult (8) & $3.39 \pm 0.58$ \\
Immature (12) & $6.09 \pm 0.72^{* *}$ \\
Estradiol-treated & $4.81 \pm 0.42^{* * *}$ \\
immature (6) & \\
\hline
\end{tabular}

Values are expressed as mean \pm standard deviation. * Significantly different from intact and testosterone-treated castrated rats at $\mathrm{p}<0.005$.

** Significantly different from adult at $\mathrm{p}<0.001$ and from estradiol-treated immature rats at $\mathrm{p}<0.01$.

*** Difference between adult and estradiol-treated immature rats was significant at $\mathrm{p}<0.005$.

Number of animals used for assay of cAMP-binding activity is given in parentheses.

castration caused an elevation in the binding capacity and the enzyme activity, but the ratio of the dependent to the independent enzyme activity does not differ significantly from those of the other two experimental groups.

The importance of the cAMP-binding protein and cAMP-dependent protein kinase for the functional differentiation of mouse mammary epithlial cells was pointed out by Majumder and Turkington (1971) and a central role of cAMP-dependent protein kinase in the hormonal regulation of carbohydrate metabolism in the skeletal muscle (Posner et al., 1965; Schlender et al., 1969). and of lipid metabolism in the adipose tissue (Corbin et al., 1970; Huttunen et al., 1970). In the present work, changes in both the activity of protein kinases and the capacity of cAMP-binding were detected in target tissues of sex hormones under different hormonal statuses, however, physiological implications of these observations still remains uncertain. Efforts will have to be focused to disclosing the real 
protein substrate of the protein kinase in the cell to throw further insight into the role of protein kinase in the regulation of cellular function and metabolism.

\section{References}

Ahmed, K. (1971). Biochim. Biophys. acta 243, 38 .

Appleman, M. M., E. Belocopitow and H. N. Torres (1964). Biochem. Biophys. Res. Commun. 14, 550.

Blat, C. and J. E. Loeb (1971). FEBS Letters 18, 124.

Chaubaut, A. M., F. Leray and J. Hanoue (1971). Ibid. 15, 328.

Corbin, J. D., E. M. Reiman, D. A. Walsh and E. G. Krebs (1970). J. Bol. Chem. 245, 4999.

Cross, M. E. and M. G. Ord (1971). Biochem. J. 124, 241.

Gill, G. N. and L. D. Garren (1971). Proc. Nat. Acad. Sci. U.S.A. 68, 786.

Griffin, D. M. and C. M. Szego (1968). Life Sci. 7, 1017.

Hechter, O., K. Yoshinaga, D. K. Halkerstone and K. Birchall (1967). Arch. Biochem. Biophys. 122, 449.

Huttunen, J. K., D. Steinberg and S. E. Mayer (1970). Biochem. Biophys. Res. Commun. 41, 1350.

Ichii, S. (1972). Endocrinol. Japan. 19, 229.

Kuo, J. F. and P. Greengard (1969). Proc.
Nat. Acad. Sci. U.S.A. 64, 1349.

Kuo, J. F., B. K. Krueger, J. R. Sanes and P. Greengard (1970). Biochim. Biophys. acta 212, 79.

Lafreniere, R. T. and R. L. Singhal (1971). Steroids 17, 323.

Lowry, O. H., N. J. Rosenbrough, A. L. Farr and R. V. Randall (1951). J. Biol. Chem. 193, 265.

Majumder, G. C. and R. W. Turkington (1971). Ibid. 246, 5545.

Posner, J. B., R. Stern and E. G. Krebs (1965). Ibid. 240, 982.

Schlender, K. K., S. H. Wei and C. VillarPalasi (1969). Biochim. Biophys. acta 191, 272.

Sharma, S. K. and G. P. Talwar (1970). J. Biol. Chem. 245, 1513.

Shlatz, L. and G. V. Marinetti (1971). Biochem. Biophys. Res. Commun. 45, 51.

Singhal, R. L., R. Vijayvargiya and G. M. Ling (1970). Science 168, 261.

Takeda, M. and Y. Ohga (1972). Taisha 9, 760 (in Japanese).

Thomas, J. A., B. Czap, G. M. Ling and R. L. Singhal (1972). Hormone \& Met. Res. 4, 313

Walsh, D. A., J. P. Perkins and E. G. Krebs (1968). J. Biol. Chem. 243, 3763.

Walton, G. M., G. N. Gill, I. B. Abrass and L. D. Garren (1971). Proc. Nat. Acad. Sci. U.S.A. 68, 880.

Yamamura, H., A. Kumon, K. Nishiyama, M. Takeda and Y. Nishizuka (1971). Biochem. Biophys. Res. Commun. 45, 1560. 